УДК 633.85

(C) 2017

\author{
Мельник А. В., доктор сільськогосподарських наук, професор, \\ Бондарчук I. Л., аспірант \\ Сумський національний аграрний університет
}

Присяжннюк О. І., кандидат сільськогосподарських наук, стариий науковий співробітник Інститут біоенергетичних культур і цукрових буряків НААНУ

\title{
КЛАСТЕРНИЙ АНАЛІЗ УРОЖАЙНОСТІ СОРТІВ ТА ГІБРИДІВ РІПАКУ ОЗИМОГО В РІЗНИХ АГРОКЛІМАТИЧНИХ ЗОНАХ УКРАЇНИ
}

\section{Рецензент - доктор сільськогосподарських наук, професор М. Я. Шевніков}

\begin{abstract}
Обгрунтовано використання кластерного аналізу для підбору сортів та гібридів ріпаку озимого сучасної селекиії. Дослідження проводились у 2013-2015 рр. у чотирьох різних агрокліматичних регіонах України. За вирощування в господарствах різних сортів та гібридів потрібно уникати підбору для центрального регіону Клеопатра, ПР44В30, ДК Секвоя, Демерка та ПР 45Д05. Для господарств південного регіону небажаним є поєднання двох груп сортів, а саме: Клеопатра, Черемош, НК Октан та ПР45Д05 або ж: Снігова королева, Джампер, Сітро, Демерка, Абакус, Белана, ПР44В30, ДК Секвоя та ДК Секюр. Для західного регіону близькими за продуктивністю в розрізі років досліджень є Клеопатра, ДК Секюр, НК Октан, ПР45Д06, ДК Секвоя та Сітро, а для східного регіону відповідно: Клеопатра, ПР44В30, ДК Секюр, Снігова королева та Сітро. Тобто сорти та гібриди з різних груп кластерів можна висівати в умовах одного господарства, а от в межах однієї групи кластерів - небажано.
\end{abstract}

Ключові слова: ріпак озимий, регіони вирощування, урожайність, кластерний аналіз, евклідові відстані.

Постановка проблеми. Виробництво олії з ріпаку у світовому обсягу виробництва рослинних олій відповідає $10-12 \%$, а отже в сільському господарстві ріпак займає міцні позиції як одна з основних олійних культур. Так, за даними ФАО, у 2015/2016 МР валовий збір насіння ріпаку у світі становив 63,6 млн тонн, 3 них 22,3 млн тон виробляється країнами Свропи ( $\mathrm{CC}-28)$ [6].

Накопичені наукові дані та практичний досвід виробничників дають можливість успішно вирощувати ріпак майже в усіх зонах України, однак його площі обмежені, а виробництво насіння та олії 3 нього $є$ не завжди ефективним 3 економічної точки зору. Основною причиною такого стану $\epsilon$ не тільки низька урожайність насіння цієї культури, а й не менш важливу роль відіграє правильний підбір сортів відповідно до конкретної природно-кліматичної зони $[2,4,5]$.
Застосування багатовимірних методів аналізу для оцінки нових сортів ріпаку дає можливість отримати більш точні прогнози по їx вирощуванню в різних грунтово-кліматичних зонах, та, як наслідок, уникнути недобору врожаю.

Аналіз основних досліджень і публікацій, у яких започатковано розв'язання проблеми. Відродження ріпаку як промислової олійної культури в Україні майже заново почалося 15-17 років тому. Виведення нових високоякісних сортів, розроблення інтенсивних технологій вирощування відкрили його широкі потенційні можливості. Водночас 3 тим активізація ринку сприяла створенню такої ситуації що на даний час на ринку є 230 сортів та гібридів ріпаку озимого, які можуть бути використані в різних природно-кліматичних зонах [1].

Певний сегмент ринку ріпаку в Україні займають безерукові, низькоглюкозинолатні сорти вітчизняної селекції: Івано-Франківського інституту АПВ НААНУ (9), Національного університету біоресурсів і природокористування України (6), Інституту олійних культур НААНУ (6), ННЦ «Інститут землеробства НААНУ» (3), Вінницької державної сільськогосподарської станції НААНУ (3), ТОВ «Монсанто Україна» (3), Хмельницького інституту АПВ НААНУ (3), Національного ботанічного саду ім. М. М. Гришка НАНУ (2) та низки інших вітчизняних установ. Зростає частка сортів та гібридів ріпаку озимого іноземної селекції, зокрема фірм Монсанто Технолоджі (19), Байєр КропСайєнс АГ (19), Монсанто Інтернешнл Сьорл (17), Норддойче Пфланценцухт Ганс-Георг Лембке КГ (16), Піонер Хай-Бренд (13), Дойче Заатфеределунг АГ (13), Дікманн ГимХ і Ко. КГ (12), Євраліс Семанс (11), Коссад Семанс (12), Піонер Семена Холдинг (10), Піонер Оверсіз Корпорейшн (8), Сингента Кроп Протекшн (6), КВС ЗААТ АГ (5), Сінгента Сідз С.А.С. (5), Лімагрейн Юроп (5), 


\section{СІЛЬСЬКЕ ГОСПОДАРСТВО. РОСЛИННИЦТВО}

ТОВ «Сингента» (4), ТОВ «Монсанто Україна» (3), Маїсадур Семанс (3).

Отже, в такому різноманітті сортів та гібридів украй необхідно, за допомогою сучасних агрономічних та статистичних методів, підібрати кращі, які будуть реалізовувати генетичний потенціал в конкретних кліматичних умовах. Варто зазначити, що кластерний аналіз, сутність якого полягає у здійсненні класифікації об'єктів дослідження на «кластери» або групи дуже схожих об'єктів, дає змогу класифікувати об'єкти не за однією ознакою, а за декількома одночасно. А отже, мета кластерного аналізу, що полягає в пошуку наявних структур, що виражається в утворенні груп схожих між собою об'єктів-кластерів, цілком відповідає поставленим нами задачам - комплексної класифікації досліджуваних сортів ріпаку.

Мета досліджень - обгрунтування використання кластерного аналізу для підбору сортів та гібридів ріпаку озимого сучасної селекції в різних агрокліматичних регіонах України.

Завдання - за допомогою кластерного аналізу виділили групи сортів та гібридів придатних для вирощування в різних агрокліматичних регіонах України.

Умови і методика проведення досліджень. Дослідження проводились у 2013-2015 pp. у чотирьох різних агрокліматичних регіонах України. Захід - місце розміщення: с. Камянки, Підволочиський район, Тернопільська область, ТОВ «Медобори». Грунт - чорнозем типовий опідзолений, характеризується низьким вмістом доступного азоту, середньозабезпечений обмінними формами фосфору та калію. Вміст гумусу $-3,2 \%, \mathrm{pH}-7,4$. Південь - місце розташування: Миколаївська область, Жовтневий район, с. Шевченкове. Грунт - темно-каштанові середньосуглинкові слабко солонцюваті, характеризуються низьким вмістом доступного азоту, середньозабезпечені обмінними формами фосфору та калію. Вміст гумусу $-3,0 \%, \mathrm{pH}-$ 7,5. Схід - місце розташування: ТОВ «Балакліївський ХПП», Харківська область, Балаклійський p-н, с. Вишнева. Грунт - чорнозем типовий, пилувато-легкосуглинковий, $\mathrm{pH}-6,8$, показники доступного фосфору та обмінного калію знаходяться в межах середніх значень. Центр місце знаходження: ДПДГ «9 січня», с. Ялосовецьке, Хорольський р-н, Полтавська область. Грунт - чорнозем типовий легкосуглинковий, вміст гумусу $-4,1 \%, \mathrm{pH}-7,6$.

Схема досліджень передбачала вивчення сортів ріпаку озимого: Клеопатра, Снігова королева - власник Національний університет біоресурсів i природокористування; Демерка, Черемош Івано-Франківський інститут АПВ НААНУ; Брентано, Белана, Джампер - Байєр КропСайєнс АГ; Абакус, НПЗ 9800 - Норддойче Пфланценцухт Ганс-Георг Лембке КГ; ПР45Д05, ПР44В30 Піонер Хай-Бренд Світзерленд; ДК Секвоя, ДК Секюр - Монсанто Інтернешнл Сьорл; Сітро, Хорнет - Дойче Заатфеределунг АГ; НК Октан Сінгента Сідз С.А.С.

Параметри досліду: $1 \mathrm{a}=16, \mathrm{n}=4$, облікова ділянка $-25,0 \mathrm{~m}^{2}$. Розміщення ділянок: повторень - чотириярусне, варіантів - рендомізоване. Попередник ріпаку - зернові культури. Спосіб сівби - рядковий (15 cм). Норма висіву 0,7 млн шт./га. Застосовувалася інтегрована система захисту 3 урахуванням порогів шкодочинності хрестоцвітих блішок, попелиці та ріпакового квіткоїду. Статистичну обробку отриманих даних проводили за допомогою комп'ютерної програми STATISTICA [3]. У практиці найбільш часто використовується алгоритм деревоподібної кластеризації, який полягає у формуванні кластерів відмінності або відстані між об'єктами. Такі відстані можуть визначатися в одновимірному або багатовимірному просторі і найпростіше їх можна обчислити через евклідові відстані. Метою процедури кластеризації $є$ виявлення кластерної структури. Розбивання вибірки на групи подібних об'єктів дає змогу спростити подальшу обробку даних $\mathrm{i}$ прийняття рішень, застосовуючи до кожного кластера свій метод аналізу. Евклідова відстань $\epsilon$ геометричною відстанню в багатовимірному просторі й обчислюється в такий спосіб: відстань $(\mathrm{x}, \mathrm{y})=\left\{\mathrm{S}_{\mathrm{i}}\left(\mathrm{x}_{\mathrm{i}}-\mathrm{y}_{\mathrm{i}}\right)^{2}\right\}^{1 / 2}$. Зазначимо, що евклідова відстань (і пї квадрат) обчислюється за вихідними, а не за стандартизованими даними. У абсолютній більшості випадків дерево кластеризації - це найбільш наглядний спосіб представлення результатів кластерного аналізу.

Результати досліджень. Досліджувані нами сорти та гібриди ріпаку озимого мають не тільки біологічні відмінності, викликані їх генетичним різноманіттям, а й можуть у багатьох випадках реагувати на зміну умов вирощування однаково тільки через те, що до їх генотипу залучено приблизно однакові групи генів у результаті селекції в одній і тій самій установі. Щоб довести, чи правдиве таке твердження, ми провели кластерний аналіз.

Для перевірки нашої гіпотези проведено кластерний аналіз. На рис. 1-4 наведено дерево кластеризації сортів та гібридів ріпаку озимого за показником урожайності. Зважаючи на те, що дослідження ми виконували в різних за 


\section{СІЛЬСЬКЕ ГОСПОДАРСТВО. РОСЛИННИЦТВО}

агрокліматичними показниками регіонах України, то і групування сортів та гібридів ріпаку проводимо в межах кожного 3 регіонів. Аналізуючи результати кластеризації сортів та гібридів ріпаку озимого за показниками врожайності по центральному регіону, слід зазначити, що сорти ріпаку Клеопатра, ПР44В30, ДК Секвоя, Демерка та ПР45Д05 мають найбільш тісні закономірності в формуванні продуктивності. Тобто 3 року в рік закономірності формування їх урожайності в залежності від впливу погодних умов доволі подібні, так сорти і гібриди приблизно однаково реагують на умови вирощування.

Варто загострити увагу на тому, що в даному кластері гібриди ПР44В30 та ПР45Д05 належать одному оригінатору - Піонер Семена Холдінг ГезмбХ. Тобто, зважаючи на їх однакову реакцію на умови вирощування в роки досліджень, ми не можемо рекомендувати використовувати в господарствах обидва цих гібриди в якості страхового фонду від неврожаю в випадку дії негативних умов вирощування. Досліджувані гібриди приблизно однаково реагують на умови вирощування, тому і на дію несприятливих факторів середовища вони можуть зреагувати аналогічно.

Якщо аналізувати результати кластеризації сортів та гібридів ріпаку озимого по центральному регіону в цілому, то найбільш віддаленими від вищенаведених гібридів $є$ такі, як ДК Секюр та Хорнет, а решта досліджуваних сортів та гібридів примикає до першого кластера тією чи іншою мірою, демонструючи віддаленість від основної групи сортів. А отже, переважна більшість досліджуваних нами сортів та гібридів ріпаку озимого по-різному реагує в різні роки на вплив умов вирощування та погодно-кліматичних факторів, але в межах року або ж дії якогось несприятливого фактору їх реакція може бути однаковою i полягати в зниженні продуктивності.

Основні результати кластеризації сортів та гібридів ріпаку озимого за показниками врожайності для південного регіону подано на рис. 2. На відміну від центрального регіону тут можна виділити два кластери, за якими i класифікуємо досліджувані сорти та гібриди. До першого кластеру входять Клеопатра, Черемош, НК Октан та ПР45Д05 - усі належать до різних установ-оригінаторів. До другого кластеру можна віднести дещо більшу групу сортів та гібридів ріпаку озимого, а саме: Снігова королева, Джампер, Сітро, Демерка, Абакус, Белана, ПР44В30, ДК Секвоя та ДК Секюр. Варто зазначити, що Белана та Джампер селекції Байєр Кропсаєнс АГ, а ДК Секвоя та ДК Секюр - Монсанто Інтернешнл Сьорл.

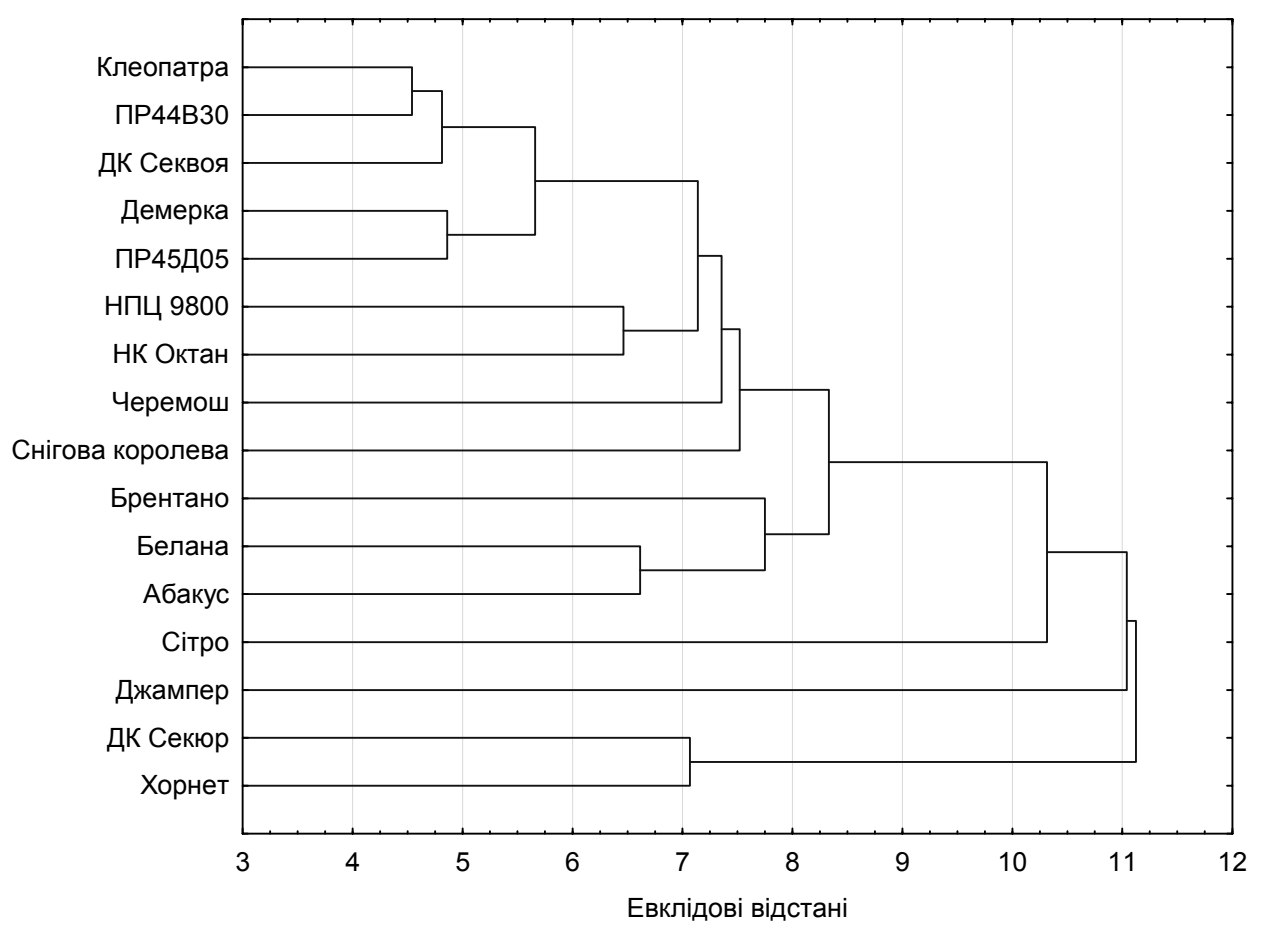

Рис. 1. Кластеризація сортів та гібридів ріпаку озимого за показниками врожайності (2013-2015 рр., центральний регіон) 


\section{СІЛЬСЬКЕ ГОСПОДАРСТВО. РОСЛИННИЦТВО}

Брентано, Хорнет та НПЦ 9800 за продуктивністю в умовах південного регіону лежать найбільш віддалено від усіх досліджуваних нами сортів та гібридів ріпаку озимого.
На наступному графіку кластеризації сортів та гібридів ріпаку озимого за показниками врожайності наведено дані по західному регіону (рис. 3).

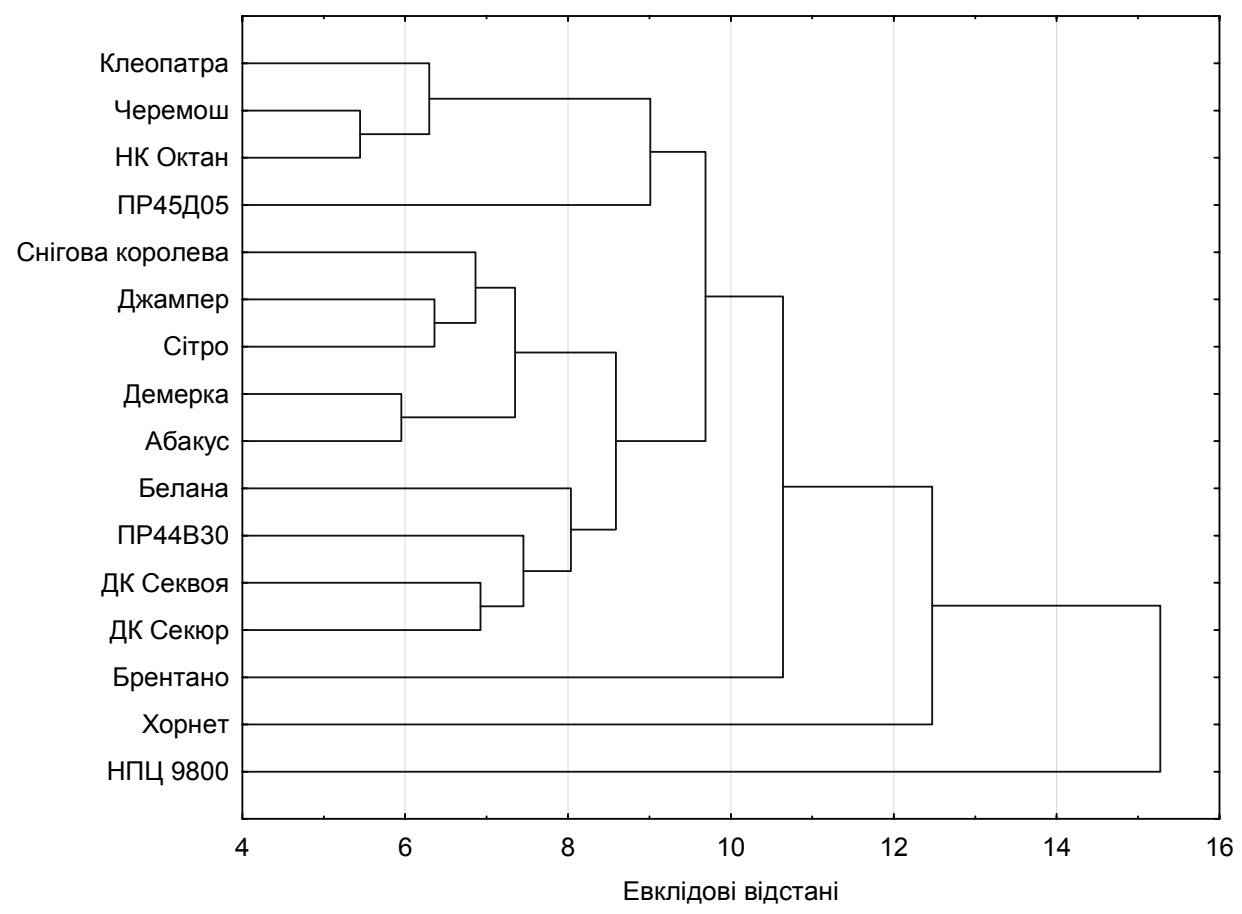

Рис. 2. Кластеризація сортів та гібридів ріпаку озимого за показниками врожайності (2013-2015 рр., південний регіон)

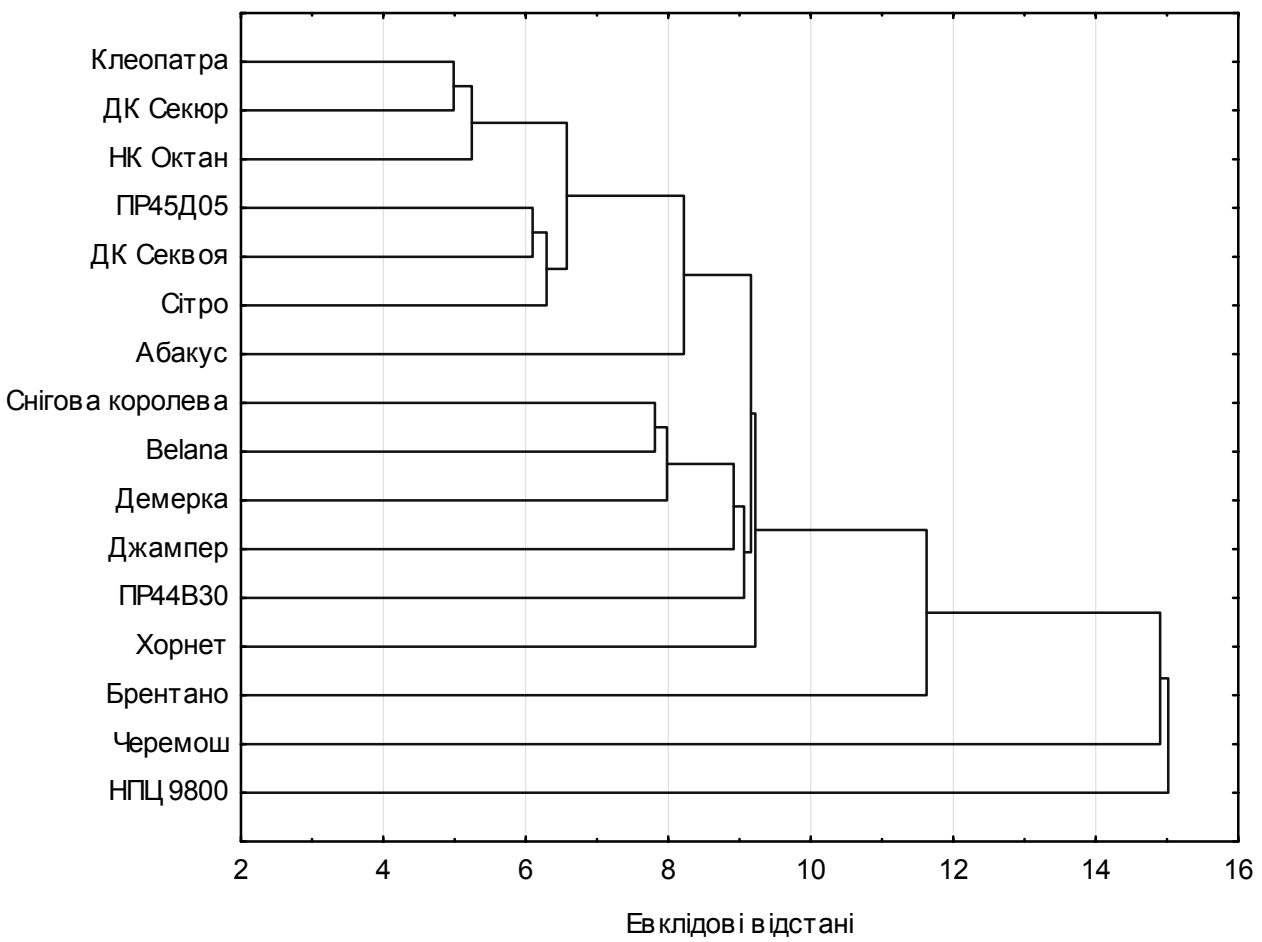

Рис. 3. Кластеризація сортів та гібридів ріпаку озимого за показниками врожайності (2013-2015 рр., західний регіон) 
По аналогії з центральним регіоном в даному випадку, під час аналізу даних західного регіону можна виділити один кластер, до якого примикає решта сортів. Тобто подібність норми реакції досліджуваних нами сортів та гібридів ріпаку озимого в даному регіоні викликана передусім несприятливими умовами вирощування, а зокрема - перезимівлі, - що в цілому накладає обмеження на їх урожайність і призводить до специфічного представлення графічного групування дослідних даних.

A отже, близькими за продуктивністю в розрізі років досліджень є Клеопатра, ДК Секюр, НК Октан, ПР45Д05, ДК Секвоя та Сітро. Усі досліджувані нами сорти та гібриди належать до різних установ-оригінаторів.

По аналогії з іншими регіонами Брентано, Черемош та НПЦ 9800 за продуктивністю в умовах західного регіону лежать найбільш віддалено від усіх досліджуваних нами сортів та гібридів ріпаку озимого.

Результати кластеризації сортів та гібридів ріпаку озимого за показниками врожайності для східного регіону наведено на рис. 4.

За результатами класифікації сортів та гібридів ріпаку озимого можна сказати, що для східного регіону найбільш близькими за продуктивністю $є$ : Клеопатра, ПР44В30, ДК Секюр, Снігова королева та Сітро, причому Клеопатра, Снігова королева належать до установи-оригінатора НУБІП. Якщо аналізувати найбільш віддалені за ознакою продуктивності сорти та гібриди, то до них можна віднести Брентано, Черемош та НПЦ 9800.

Висновок. 3 метою отримання стабільної та високої продуктивності ріпаку озимого в умовах основних агрокліматичних зон вирощування потрібно дотримуватись принципів насичення виробництва різними сортами та гібридами, для зменшення ризиків втрати посівів в осінньо-зимовий період та недобору врожаю за рахунок дії несприятливих факторів навколишнього середовища.

За вирощування в господарствах різних сортів та гібридів потрібно уникати підбору для центрального регіону Клеопатра, ПР44В30, ДК Секвоя, Демерка та ПР45Д05. Для господарств південного регіону небажаним $\epsilon$ поєднання двох груп сортів, а саме: Клеопатра, Черемош, НК Октан та ПР45Д05 або ж: Снігова королева, Джампер, Сітро, Демерка, Абакус, Белана, ПР44В30, ДК Секвоя та ДК Секюр. Тобто сорти та гібриди з різних груп кластерів можна висівати в умовах одного господарства, а от у межах однієї групи кластерів - небажано.

Для західного регіону близькими за продуктивністю в розрізі років досліджень є: Клеопатра, ДК Секюр, НК Октан, ПР45Д06, ДК Секвоя та Сітро, а для східного регіону відповідно: Клеопатра, ПР44В30, ДК Секюр, Снігова королева та Сітро.

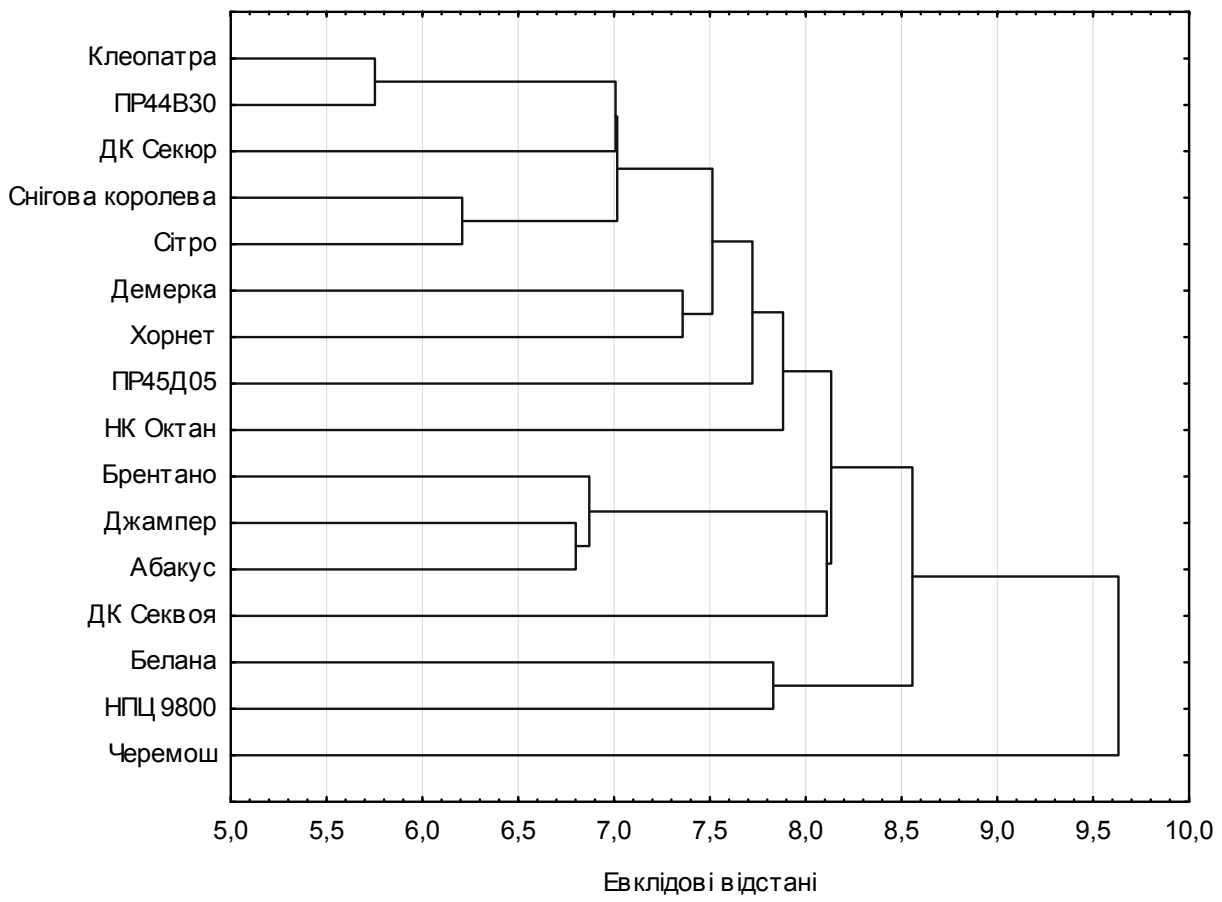

Рис. 4. Кластеризація сортів та гібридів ріпаку озимого за показниками врожайності (2013-2015 рр., східний регіон) 


\section{БІБЛІОГРАФІЯ}

1. Державний реєстр сортів рослин, придатних для поширення в Україні на 2016 рік. - К. : ТОВ «Алефа», 2016. - 300 с.

2. Донець А. О. Удосконалення технології вирощування ріпаку озимого в умовах півдня України : автореф. дис. на здобуття наук. ступеня к.с.-г.н. : спец. 06.01.09 «Рослинництво» / А. О. Донець. - Херсон, 2013. - 20 с.

3. Комп'ютерні методи в сільському господарстві та біології : навчальний посібник [Царенко О. М., Злобін Ю. А., Скляр В. Г., Панченко С. М.]. - Суми : Університетська книга, 2000. $-203 \mathrm{c}$.
4. Мельничук С. Л. Технологічні та екологічні особливості формування продуктивності ріпаку озимого в Правобережному Лісостепу України. : автореф. дис. на здобуття наук. ступеня к.с.-г.н. : спец. 06.01.09 «Рослинництво» / С. Л. Мельничук. - К., 2013. - 20 с.

5. Наукові основи агропромислового виробництва в зоні Лісостепу України / [Зубець В. М. та ін.] ; за ред. В. М. Зубця. - К. : Логос, 2004. $776 \mathrm{c}$.

6. Food and agriculture organization of the United Nations. FAO [Електронний ресурс]. - Режим доступу : http://faostat.fao.org/site/636/default. aspx \#ancor. 